\title{
Prinsip sebagai Dasar Pelaksanaan Bimbingan dan Konseling di Sekolah
}

\author{
Indah Saputri \\ Universitas Negeri Padang \\ email : indahsaputri032@gmail.com
}

\begin{abstract}
Abstrak : Bimbingan dan konseling di sekolah merupakan salah satu usaha dalam membantu siswa agar dapat memahami dirinya sendiri, seperti potensi dan kelemahan - kelemahannya. Usaha yang dilakukan berupa usaha professional yang sangat memerlukan pengetahuan dan keterampilan yang khusus serta harus memiliki kepribadian yang sesuai untuk profesi tersebut. Di dalam bimbingan dan konseling tidak hanya pelayanan yang diberikan tetapi terdapat pula pedoman berupa prinsip - prinsip dalam bimbingan dan konseling. Prinsip - prinsip dalam bimbingan dan konseling yang berkaitan dengan sasaran layanan, prinsip yang berkaitan secara langsung dengan individu, prinsip yang berkaitan dengan pelayanan, serta prinsip yang berkaitan dengan tujuan dan pelaksanaan pelayanan.
\end{abstract}

Kata Kunci: Prinsip, Bimbingan dan Konseling, Sekolah

\begin{abstract}
Guidance and counseling in schools is an effort to help students understand themselves, such as their potentials and weaknesses. The business that is carried out is in the form of a professional business that really requires specific knowledge and skills and must have a personality that is suitable for that profession. In guidance and counseling, not only services are provided but there are also guidelines in the form of principles in guidance and counseling. Principles in guidance and counseling relating to service objectives, principles directly related to individuals, principles relating to service, and principles relating to the purpose and implementation of services.
\end{abstract}

Keywords: Principles, Guidance and Counseling, School

\section{PENDAHULUAN}

Siswa memiliki berbagai potensi yang bisa dikembangkan seperti kemampuannya dalam berkreasi, tidak tergantung orang lain, bertanggung jawab, dan mampu menyelesaikan masalah yang akan dihadapinya. Tetapi, jika dipandang sebagai individu yang berhubungan langsung dengan lingkungan, siswa pasti tidak lepas dari masalah. Dengan adanya kesadaran terebut, siswa memerlukan sebuah bantuan dan bimbingan orang lain dalam mengambil tindakan yang tepat dan sesuai potensi yang terdapat dalam dirinya. Salah satu yang 
berperan besar dalam bimbingan ini adalah sekolah yang merupakan fungsi untuk memberikan pengetahuan tetapi juga menegmbangkan keseluruhan kepribadian seorang siswa.

Sebagai seorang konselor atau guru BK haruslah memiliki prinsip prinsip Bimbingan dan Konseling sebagai sebuah pedoman. Pentingnya prinsip prinsip bimbingan dan konseling sehinggan tidak dapat diabaikan begitu saja, karena prinsip - prinsip tersebut menjelaskan tentang pokok - pokok dasar dalam pemikiran yang dijadikan pedoman dalam pelaksanaan program pelayanan sebuah bimbingan. Prinsip - prinsip bimbingan dan konseling juga dijadikan sebagai seperangkat landasan praktis atau aturan pelaksanaan yang harus diikuti dalam pelksanaan sebuah program pelayanan pada bimbingan dan konseling di sekolah.

\section{PEMBAHASAN}

Prinsip merupakan permulaan suatu cara tertentu yang akan menciptakan hal-hal lain, yang keberadaannya tergantung dari permulaan itu. Bimbingan konseling memerlukan suatu prinsip atau aturan pelaksanan dalam menjalankan program pelayanan bimbingan. Menurut Prayinto dan Amti (1994:220) rumusan prinsip-prinsip bimbingan dan konseling pada umumnya berkaitan dengan sasaran pelayanan, masalah klien, tujuan dan proses penanganan sebuah masalah, program pelayanan dan penyelenggaraan pelayanan.

Adapun rumusan prinsip-prinsip bimbingan dan konseling yang berkaitan dengan objek dalam pelayanan bimbingan yaitu prinsip-prinsip yang berkaitan dengan sasaran layanan, prinsip yang berkaitan dengan permasalahan idividu, prinsip yang berkaitan dengan program pelayanan dan yang terakhir prinsip yang berkaitan dengan tujuan dan pelaksanaan pelayanan. Dari empat rumusan tersebut, bimbingan dan konseling akan tercapai sesuai keinginan konselor dan klien.

\section{Prinsip - Prinsip Umum}

Adapun prinsip prinsip bimbingan dan konseling secara umum antara lain : 1) Bimbingan harus berfokus pada individu yang sedang di bimbingnya. 2) Bimbingan berupa memberikan bantuan supaya individu yang dibimbing mampu mengarahkan dirinya dan menghadapi permasalahan dalam hidupnya. 2) Pemberian bantuan diselaraskan dengan kebutuhan individu yang sedang dibimbing. 3) Bimbingan berkaitan dengan sikap dan tingkah laku individu. 4) Pelaksanaan bimbingan dan konseling diawali dengan mengidentifikasi kebutuhan yang dirasakan individu yang dibimbing. 5) Upaya pemberian bantuan harus dilakukan secara fleksibel. 6) Program bimbingan dan konseling harus dirumuskan sesuai dengan program pendidikan dan pembelajaran di sekolah yang bersangkutan. 7) Implementasi program bimbingan dan konseling harus dipimpin oleh orang yang memiliki potensi dan keahlian dalam bidang bimbingan dan 
konseling serta pelaksanaannya haruslah bekerjasama dengan berbagai pihak yang terkait hal tersebut 8) Untuk mengetahui hasil dari upaya pelayanan bimbingan dan konseling, harus diadakan penilaian atau ekuivalensi secara teratur dan berkesinambungan.

\section{Prinsip-Prinsip Khusus (Berhubungan dengan Siswa)}

Adapun prinsip - prinsip bimbingan konseling secara khusus yang berhubungan langsung dengan siswa anatar lain : 1) Pelayanan BK harus diberikan langsung kepada semua siswa. 2) Harus ada kriteria untuk mengatur prioritas pelayanan bimbingan dan konseling kepada individu atau siswa. 3) Program pemberian bimbingan dan konseling harus berpusat pada siswa. 4) Pelayanan dan bimbingan konseling di sekolah dan madrasah harus dapat memenuhi kebutuhan-kebutuhan individu bersangkutan yang sifatnya beragam dan luas. 5) Keputusan akhir dalam proses BK dibentuk oleh siswa sendiri. 6) Siswa yang telah memperoleh bimbingan, harus secara berangsur-angsur dapat menolong dirinya sendiri.

\section{Prinsip - Prinsip Khusus (Berhubungan dengan Pembimbing)}

Adapun prinsip - prinsip bimbingan konseling secara khusus yang berhubungan langsung dengan pembimbing antar lain: 1) Konselor harus melakukan tugas sesuai dengan kemampuannya masing-masing. 2) Konselor di sekolah dipilih atas dasar kualifikasi kepribadian, pendidikan pengalaman, dan kemampuan. 3) Sebagai tuntutan profesi, pembimbing atau konselor harus senantiasa berusaha mengembangkan dirinya dan keahliannya melalui berbagai kegiatan. 4) Konselor hendaknya selalu mempergunakan berbagai informasi yang tersedia tentang siswa yang dibimbing beserta lingkungannya sebagai bahan yang membantu innsividu yang bersangkutan kearah penyesuaian diri yang lebih baik. 5) Konselor harus menghormati, menjaga kerahasiaan informasi tentang siswa yang dibimbingnya. 6) Konselor harus melaksanakan tugasnya hendaknya mempergunakan berbagai metode yang sama.

\section{Prinsip Yang Berkenaan dengan Tujuan Pedidikan}

Pelaksanaan pelayanan bimbingan dan konseling (baik yang terprogram atau incidental) dimulai dengan pemahaman tentang tujuan layanan. Tujuan ini selanjutnya akan diwujudkan melalui proses tertentu oleh seorang konselor. Dalam pelaksanaan program bimbingan dan konseling konselor perlu mengadakan kerja sama dengan berbagai pihak, baik dari dalam lembaga maupun dari luar lembaga agar tercapainya perkembangan peserta didik secara optimal. Prinsip-prinsip yang berkenaan denga hal tersebut adalah : 1) Tujuan akhir bimbingan dan konseling adalah kemandirian setiap individu. Oleh karena itu pelayanan bimbingan dan konseling harus diarahkan untuk mengembangkan konseli agar mampu membimbing diri sendiri dalam menghadapi kesulitan atau 
permasalahan yang dihadapinya. 2) Dalam proses konseling keputusan yang diambil dan hendak dilakukan oleh konseli hendaknya atas kemauan konseli sendiri, bukan karena kemauan atau desakan dari konselor. 3) Permasalahan khusus yang dialami konseli harus ditangani oleh tenaga ahli dalam bidang yang relevan dengan permasalaha khusus tersebut. 4) Bimbingan dan konseling adalah pekerjaan profesional. Oleh jarena itu dilaksanakan oleh tenaga ahli yang telah memperoleh pendidikan dan latihan latihan khusus dalam bidang bimbingan konseling. 5) Guru dan orang tua memiliki tanggung jawab yang berkaitan dengan pelayanan bimbingan konseling. Oleh karena itu kerjasama antar konselor dengan orang tua dan guru sangat diperlukan. 6) Guru dan konselor berada dalam satu kerangka upaya pelayanan. Oleh karena itu keduanya harus mengembangkan peranan yang saling melengkapi untuk mengurangi hambatanhambatan yang menyebabkan terganggunya aktivitas belajar mengajar disekolah maupun interaksi peserta didik terhadap lingkungan dimana ia berada. 7) Untuk mengelola pelayanan bimbingan dan konseling dengan baik dan sejauh mungkin memenuhi tuntutan individu, sebaiknya didakan program penilaian dan himpunan data yang memuat hasil pengukuran dan penilaian

\section{Prinsip-prinsip berkenaan dengan permasalah individu}

Berbagai faktor yang mempengaruhi perkembangan dan kehidupan individu tidaklah selalu positif, namun faktor-faktor negatif pasti ada yang berpengaruh dan dapat menimbulkan hambatan-hambatan terhadap kelangsungan perkembangan dan kehidupan individu yang berupa masalah. Pelayanan BK hanya mampu menangani masalah klien secara terbatas yang berkenaan dengan : 1) BK berurusan dengan hal-hal yang menyangkut pengaruh kondisi mental atau fisik individu terhadap penyesuaian dirinya dirumah, disekolah serta dalam kaitannya dengan kontak sosial dan pekerjaan, dan sebaliknya pengaruh lingkungan terhadap kondisi mental dan fisik individu. 2) Kesenjangan sosial, ekonomi dan kebudayaan merupakan faktor timbulnya masalah pada invidu yang kesemuanya menjadi perhatian utama pelayanan BK.

\section{Prinsip yang Berhubungan dengan pengorganisasian}

Adapun prinsip - prinsip bimbingan konseling yang berhubungan dengan siswa pengorganisasian anatar lain : 1) bimbingan dan konseling harus dilaksanakan secara sistematis dan berkelanjutan. 2) Pelaksanaan bimbingan dan konseling ada di kartu pribadi (commulative record) bagi setiap siswa. 3) program pelayanan bimbingan dan konseling harus disusun sesuai dengan kebutuhan sekolah atau madrasah yang bersangkutan. 4) Harus ada pembagian waktu antar pembimbing, sehingga masing-masing pembimbing. 5) Pendapat kesempatan yang sama dalam memberikan bimbingan dan konseling.Bimbingan dan konseling dilaksanakan dalam situasi individu atau kelompok sesuai dengan masalah yang dipecahkan dan metode yang dipergunakan dalam mememcahkan masalah terkait. 6) Dalam menyelenggarakan pelayanan bimbingan dan 
konseling, sekolah dan madrasah harus bekerja sama dengan berbagai pihak. 7) Kepala sekolah atau madrasah merupakan penanggung jawab utama dalam penyelenggaraan bimbingan dan konseling di sekolah.

\section{KESIMPULAN}

Berdasarkan penjabaran diatas prinsip-prinsip bimbingan dan konseling yang berkaitan dengan objek dalam pelayanan bimbingan yaitu prinsip-prinsip yang berkaitan dengan sasaran layanan, prinsip yang berkaitan dengan permasalahan idividu, prinsip yang berkaitan dengan program pelayanan dan yang terakhir prinsip yang berkaitan dengan tujuan dan pelaksanaan pelayanan. Dari empat rumusan tersebut, bimbingan dan konseling bisa dinyatakan tercapai apabila telah sesuai keinginan konselor dan klien. Jadi, sebagai calon konselor yang baik, maka sangatlah penting dalam mempelajari dan mengetahui dasardasar tentang prinsip-prinsip bimbingan konseling, baik prinsip umum dan prinsip khususnya. Yang mana bagi kita seorang calon pendidik berguna dalam melakukan pembelajaran di kelas nantinya.

\section{DAFTAR PUSTAKA}

Abin Syamsuddin Makmun. 2003. Psikologi Pendidikan. Bandung : PT Rosda Karya Remaja.

Mugiarso, Heru. et al. 2011. Bimbingan dan Konseling. Semarang: Unnes Press Prayitno. 2004. Dasar-dasar Bimbingan dan Konseling. Jakarta: Rineka Cipta

Prayitno, Erman Amti. 2004. Dasar-Dasar Bimbingan dan Konseling. Jakarta: Rineka Cipta

Sukardi, Ketut Dewa. 2002. Pengantar Pelaksanaan Program Bimbingan dan Konseling di Sekolah. Jakarta: Rineka Cipta

Tohrin. 2007. Bimbingan dan Konseling di Sekolah dan Madrasah. Jakarta :PT. Raja Grafindo Persada. 